\title{
A Simulation Framework for Assessing Physical and Wildlife Impacts of Oil and Gas Development Scenarios in Southwestern Wyoming
}

\author{
Steven L. Garman ${ }^{1,2}$ (D) \\ Received: 2 May 2016 / Accepted: 28 April 2017 / Published online: 28 June 2017 \\ (C) The Author(s) 2017. This article is an open access publication
}

\begin{abstract}
Foreseeable natural gas development in southwestern Wyoming has the potential to increase sagebrush fragmentation and risks to resident wildlife species. The ability to balance future development with conservation goals, however, is enhanced by advances in directional-drilling technologies that use multiple wells per pad and produce less surface disturbance than conventional drilling methods. To evaluate the conservation potential of this technology, I developed an energy footprint model that simulates well, pad, and road patterns for oil and gas recovery options that vary in well types (vertical and directional) and number of wells per pad and use simulation results to quantify physical and wildlife-habitat impacts. I applied the model to assess tradeoffs among 10 conventional and directional-drilling scenarios in a natural gas field in southwestern Wyoming. Scenarios spanned a gradient in the number of vertical and directional wells, and in number of pads (2000 to 250), but all extracted the same amount of gas over a 15 -year period. Reducing pad numbers with directional-drilling technology reduced surface disturbance area and impacts on spatially extensive habitats (48$96 \%$ of study area) such as sagebrush-obligate songbird habitat, elk winter range, and sagebrush core area. Impacts declined for spatially restricted mule deer migration corridors ( $24 \%$ of study area) and greater sage-grouse leks until energy infrastructure densities within corridors and near leks were
\end{abstract}

Steven L. Garman

slgarman@usgs.gov

1 U.S. Geological Survey, Geosciences and Environmental Change Science Center, PO Box 25046, DFC, MS 980,

Lakewood, CO 80225, USA

2 Present address: Bureau of Land Management, National Operations Center, PO Box 25047 Bldg. 50, Denver Federal Center,

Lakewood, CO 80225, USA similar to the initial landscape. Scenario simulations and tradeoff assessments such as illustrated in this study are intended to help decision-makers identify development designs that best achieve both energy and conservation goals.

Keywords Oil and gas development · Directional drilling . Simulation modeling $\cdot$ Wildlife impacts $\cdot$ Wyoming

\section{Introduction}

Energy development within sagebrush (Artemisia spp.) landscapes has emerged as a topical conservation issue [1]. Rangewide loss, fragmentation, and degradation of sagebrush communities in the early part of the last century have been attributed to agricultural conversion [2,3], urbanization [4], excessive herbivory [5], altered fire regimes [6], and invasion of exotic plants [3]. As a result, the long-term sustainability of many wildlife populations dependent on sagebrush has been compromised $[4,7]$. In the past three decades, an emphasis on domestic fossil-fuel production accelerated the development of onshore federal mineral estates in sagebrush landscapes supporting some of the highest densities of sagebrushobligate species $[4,8]$. The removal of habitat by oil and gas infrastructure, behavioral avoidance of infrastructure by wildlife species, and infrastructure-mediated impacts to survival and reproduction due to altered predator [9] and disease dynamics [10] further fragmented sagebrush habitat [11] and elevated risks to resident wildlife populations [1, 12-14]. Assessment of future US energy demands predict continued use of fossil fuels as a primary energy source with a $20 \%$ increase in natural gas consumption over the next 25 years [15]. To help meet energy demands, growth in natural gas production is anticipated in the Intermountain West [16] with development likely concentrated in the geologic basins 
containing large onshore federal oil and gas reserves [17]. Because these basins are largely within sagebrush ecosystems [4], minimizing the physical and ecological footprint of future oil and gas recovery strategies is crucial to avoid additional risks to the remaining sagebrush habitat and attendant wildlife populations.

Conservation management of the sagebrush rangeland in southwestern (SW) Wyoming is especially important given the extent of foreseeable energy development. This 77,000$\mathrm{km}^{2}$ region (the five southwestern counties) spans the Greater Green River Basin which is the largest onshore federal natural gas reserve in the conterminous USA [18], contains a significant portion of the remaining intact sagebrush steppe [8], and supports some of the largest populations of wild ungulates [19] and sagebrush-associated wildlife species in the USA [20]. About $67 \%$ (3.2 MH) of the sagebrush habitat in SW Wyoming overlies federal mineral estates available for energy development [21http://www.blm.gov/wy/st/en/resources/ public_room/gis/datagis/state/state-own.html]. In addition to the 24,000 oil and gas wells drilled since the 1900s [22], seven federal-estate natural gas developments in early implementation or permitting phases propose drilling of 22,000 wells in conventional, coal-bed, and other unconventional oil and gas plays over the next 20+ years [23]. The potential to balance this foreseeable development and conservation goals is enhanced by recent advances in drilling technologies. The use of directional and horizontal well bores in place of conventional vertical wells allows the drilling of multiple wells from the same pad, a larger recovery area of wells (up to 259+ ha) [24], and ultimately the construction of fewer pads and roads for energy development. Compared to conventional methods, these new technologies offer numerous combinations of multi-well pad configurations (e.g., up to 64 wells/pad [25]) and well spacings. Discerning optimal build-out designs for sustainable futures requires an informed understanding of the physical and ecological impacts among a cadre of new-technology options. The ability to assess tradeoffs among these options is currently limited by the lack of energy-development forecast and analysis tools that emulate recent technological advances. Planners and decision-makers tasked with evaluating the conservation potential of build-out designs would benefit from spatially explicit approaches that readily estimate impacts for a wide range of oil and gas recovery options.

Scenario modeling is increasingly used to portray energyinfrastructure patterns and to quantify environmental impacts $[26,27]$. Modeling approaches can readily forecast patterns of numerous build-out designs and contrast impacts to identify sustainable strategies for implementation. Modeling methods applied to Wyoming have included GIS-based approaches to estimate hypothetical and anticipated development patterns $[28,29]$, and predictive forecasts of landscape-scale well densities to assess the efficacy of conservation strategies for the greater sage-grouse (Centrocercus urophasianus) [27, 30] which has been considered for listing under the Endangered Species Act [31]. Lacking from these approaches is the collective ability to dynamically model spatial patterns of surface-disturbance features such as well pads and roads and to simulate recovery technologies that vary in well-bore types, well-pad configurations, and well spacing. Also, previously used methods lack the spatial detail to evaluate impairment of habitat functions for a range of key species affected by energy development, such as wild ungulates, and sagebrushobligate songbirds and mammals.

I developed an apparently novel energy footprint model for spatially-detailed assessments of oil and gas development designs in SW Wyoming. The model simulates the location of wells, well pads (hereafter pads), and roads on the landscape for variable well numbers per pad (well-pad configuration), spacing, and well bore types (vertical, directional, horizontal). Customized companion procedures use simulated infrastructure patterns to quantify the physical footprint of development, habitat fragmentation, and impacts on a range of wildlife species. The footprint model and accompanying procedures is a research framework intended to enhance understanding of how new-technology options may be applied to achieve both energy production and wildlife conservation goals. Results from research applications can inform decision-makers about tradeoffs among a range of alternative build-out designs and help guide the selection of designs for implementation. Here I present the simulation framework and illustrate its utility in a comparative assessment of conventional and directional-drilling scenarios in a SW Wyoming energy field.

\section{Energy Footprint Model}

The stand-alone energy footprint model was developed in the Microsoft Visual C++ environment (vers10.0, () 2010 Microsoft Corporation) and designed to use user-provided build-out designs and geospatial data layers to simulate the annual establishment of energy infrastructure on the SW Wyoming landscape (Fig. 1), (https://my.usgs.gov/bitbucket/ projects/WLCI/repos/energy_footprint_model). Build-out designs include the duration and annual rate of development, total number of wells, number of wells per pad, the bottomhole area of development of each well, and well bore types. Designs may include a single or multiple well-pad configurations (i.e., no. of wells per pad) and the number of each wellpad combination to establish. The bottom-hole area of simulated development is tracked at the scale of a Public Land Survey System (PLSS) section which mirrors how development is regulated in SW Wyoming. Wells can be located in a section as long as the sum of the bottom-hole area of wells does not exceed the section area. When multiple well-pad configurations are specified, the one with the most wells that 


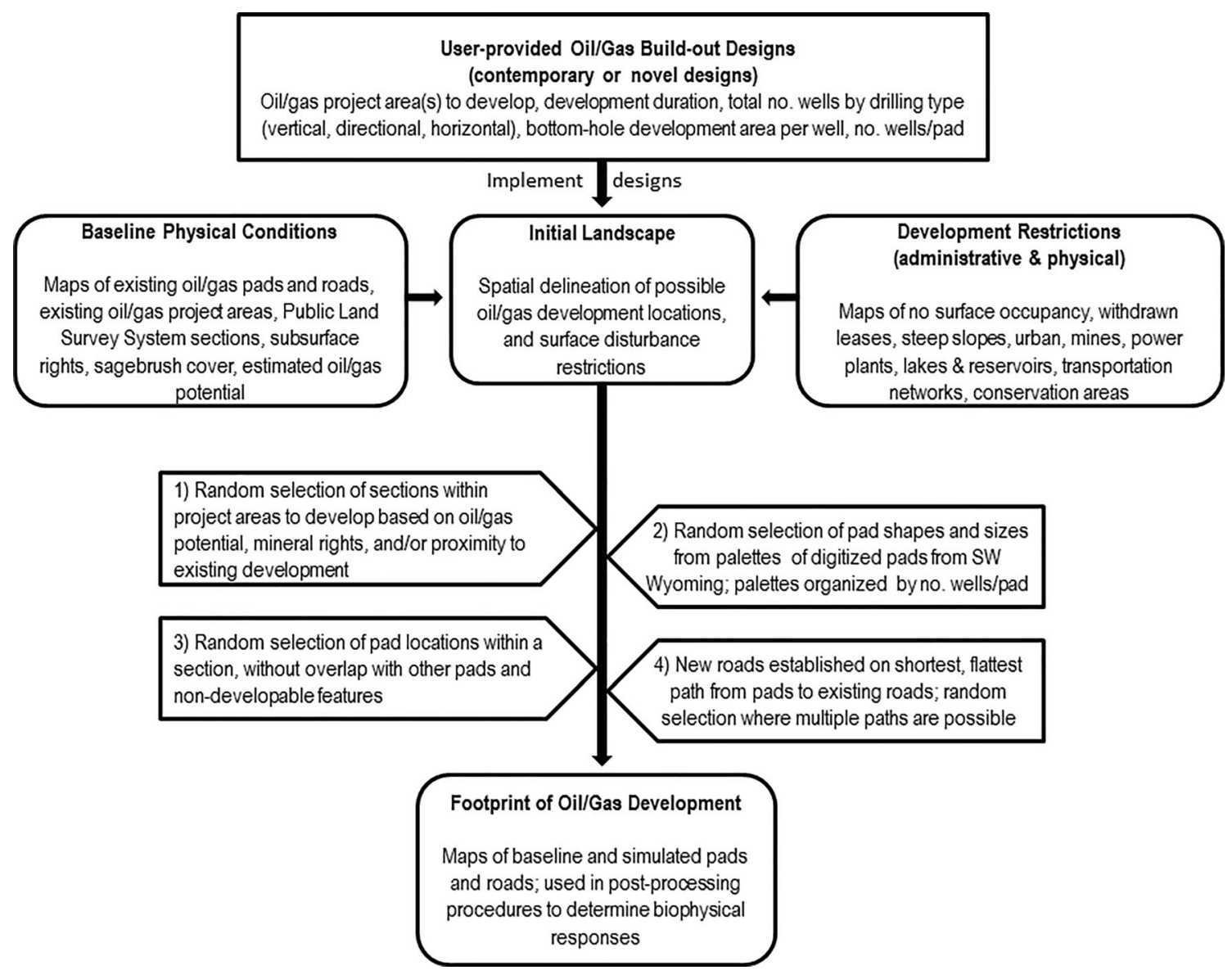

Fig. 1 Schematic overview of the energy footprint model. User-provided build-out designs specify the project area(s) and intensity of oil/gas development to simulate starting with the initial landscape. Procedures labeled 1-4 are stochastic processes that determine the sections developed within a project area, the location of pads within a section and their shape and size, and the location of new oil/gas roads, all of which are mediated

does not exceed the available bottom-hole area is established first, until the specified number of this combination is satisfied. Designs are specific to mapped energy-development areas, referred to as project areas $\left(14,495 \mathrm{~km}^{2}\right.$ or $19 \%$ of SW Wyoming), which are largely concerted efforts by private industry to develop federal and state fluid-mineral leases. Project areas can be further divided into smaller units (management units) which may have different development intensities and restrictions. Build-out specifications are applied to the initial landscape, which due to the availability of key data layers is currently circa 2012.

The initial landscape is generated from baseline physical conditions and development restrictions (Fig. 1). Baseline infrastructure conditions are derived from maps of digitized wells and pads (circa 2012) [32], and roads (circa 2009) [33] updated to 2012. Additionally, attributes of each pad and road segment are ingested in tabular form. Pad attributes consist of the establishment year, active/inactive status, no. of wells and their active/inactive status, bottom-hole area of development of each well, and corresponding bottom-hole formation (oil/ by development restrictions. These four procedures occur on an annual time step for the specified duration of a simulation. Simulation replicates repeat the design implementation starting with a unique random number seed. Each replicate results in maps of pads and roads that are used in post-processing procedures to evaluate infrastructure effects on biophysical attributes

gas play). Road attributes include road type (e.g., interstate, oil/gas road), a width estimate, and year of establishment. Center-line road vertices are also ingested and used in the road-generation process. Maps of PLSS sections and project areas identify the sections that overlap a project area and considered in the development of a project. A map of subsurface mineral rights identifies the availability of sections for oil and gas development (http://www.blm.gov/wy/st/en/resources/ public_room/gis/datagis/state/state-own.html). A map of future oil/gas potential was estimated using the correlation between geophysical properties and historical development patterns [30]. The model uses information from this map to estimate the probability of development in randomization procedures described below. Information from all 30-m maps is summarized at the scale of a section.

Maps of administrative and physical restrictions limit the placement of new pads and roads (Fig. 1). Restrictions include administrative no-surface occupancy (NSO) designations (http://www.blm.gov/wy/st/en/resources/public room/gis/ datagis/state/NSO.html) which protect areas of special 
conservation concern (e.g., buffered greater sage-grouse leks and raptor nests, historic trails, riparian corridors). Other areas where energy development is prohibited or unlikely are aggregated with NSO designations (e.g., National Parks, surface mines, population centers, reservoirs, lakes, interstate highways, $>25 \%$ slopes [34]). The model prohibits the overlap of new roads and pads with these non-developable areas. An additional administrative restriction is the limited development within greater sage-grouse (hereafter sage-grouse) core areas (SGCAs) [35]. These areas are large tracts of land with special development restrictions to protect the species' breeding (leks) and nesting areas. The model establishes pads inside of mapped SGCAs (https://wgfd.wyo.gov/Habitat/SageGrouse-Management) in accordance with the restrictions on pad density (one pad per $259 \mathrm{ha}$ ) and spacing ( $>986 \mathrm{~m}$ from a lek), and surface disturbance ( $\leq 5 \%$ surface disturbance of sagebrush within a $6.5 \mathrm{~km}$ buffer around a new pad and around leks within this buffer). Maps of non-developable areas, SGCAs, and sagebrush cover [21], used in calculating SGCA disturbance levels, are ingested as $30 \mathrm{~m}$ grids.

Over the specified development period, the model annually develops individual sections within project areas according to the specified annual allotment of wells. This involves four procedures, all of which have a random component (Fig. 1). In general, the random components account for uncertainty in the underlying processes associated with locating development on the landscape. The first procedure selects sections for development. Predicting the exact sections or even groups of sections of future development is only possible if this information is known and provided to the model as a map (e.g., a management unit within a project). Without this level of detail, prediction is problematic given the numerous factors influencing where and when oil/gas operators would be motivated to develop. Market conditions, remaining volumes of proven reservoir locations, the discovery of new "sweetspots," cost-effectiveness of expanding the existing transportation network, and the potential for new drilling technologies to economically recover fluid minerals from previously developed reservoirs [24] all mediate the location of future development. Without detailed information on locations, the model uses one or more method to weight sections, then uses weights to randomly select sections for development. Weighting methods are based on logical, possible approaches, informed in part by historical patterns and a working knowledge of developmental patterns of energy fields, but are relatively simplistic approaches to an otherwise complex process. Section weighting methods include using probability estimates of oil/gas potential, the extent of leases and subsurface mineral rights, and the number of neighboring sections with development (emulates cluster development commonly observed on the landscape). A fourth method is the use of all three criteria for weighting. In each method, section scores are accumulated (e.g., sum of oil/gas potential probabilities) and used to generate a cumulative frequency distribution with each section assigned to a relative portion of the distribution. This distribution is randomly sampled to select sections for development. Sections that are fully developed or entirely within a non-developable area are excluded from the selection process. Given the uncertainty even with each of the four approaches, a fifth and preferred method is to randomly select among the four weighting methods annually. This reduces reliance on any one particular method and incorporates a maximum level of uncertainty into the future patterns of infrastructure. Weighting method is user-provided at program initiation.

Once a section is selected, a pad shape and size is randomly selected (Fig. 1). To add a level of realism, pad shape and size are selected from palettes of actual digitized pads [32], which collectively contain 4866 pads. Each palette is a distribution of pads sizes organized by the number of wells per pad $(1-2,3-$ $5,6-8$, etc.). Average size of pads with $1-2$ wells is 1.4 ha and increases by ca. 1.0 ha with successively larger numbers of wells per pad. The organized palettes are based mostly on vertical wells due to historic drilling methods and are largely for convenience. The user must specify the palette used for each well-pad configuration in a build-out design, allowing customizing pad sizes for specific well types. For instance, the palette used for a single horizontal well will, on average, have larger pads than the palette for a single vertical well. Although pad selection is somewhat constrained by how the palettes are organized, shapes and sizes within each palette can be highly variable (especially the two smallest average sized palettes). The random selection adds plausible variability to shapes and sizes given uncertainty in how oil/gas operators will design pads in the future. A randomly selected pad consists of a 30-m gridded pattern and relative centroid and boundary vertices (magnitude and direction of displacement from the centroid) of the pad polygon. This shape information is used in subsequent procedures and to create the output pad shapefile.

A pad is randomly located within a section using predetermined random locations. To expedite processing, a random sample of points is pre-generated for each section and used to locate the centroid of a selected pad shape. Points are generated at a density of about 261 per section (total of $2.8 \mathrm{M}$ points within the WLCI study area). The density of points is sufficient to ensure a section can be fully developed in a spatially structured manner (no overlap of bottom-hole areas) that does not resemble a systematic pattern. This approach was developed from observations of historical patterns, where inter-pad distance has been largely variable with only ca. four out of 31,468 sections exhibiting a systematic pattern of pads. A randomly selected point location is first evaluated for proximity to existing development. If there is the potential for wells on the new pad to overlap existing bottom-hole area development on adjacent pads, another location is selected until there is no overlap. The centroid of a $30-\mathrm{m}$ pattern of a 
pad is "overlaid" onto a selected point to determine overlap with non-developable areas. If there is overlap, the process of selecting a location and the subsequent overlap checks continue until a suitable location is acquired. A pad is established by updating the pad map with the 30-m pattern and storing pad and well attributes. All wells on a new pad are considered drilled and operational the year the pad is established.

A road is generated along the shortest, flattest path between a new pad and an existing road. Although this is a simplistic approach, it follows general guidance of federal oil/gas development projects [36]. Using the $30-\mathrm{m}$ grid form of roads and pads, the shortest path between an existing road and pad is determined, then scrutinized for overlap with nondevelopable areas. If there is overlap, a new pathway is determined. Once a pathway is found, a 240-m buffer is applied to the pathway, and a sequential evaluation of elevation occurs starting at the existing road. Guided by changes in elevation, a new pathway is derived within this buffered zone along the flattest route and recorded in the internal road map. Where multiple routes are possible, one is randomly selected. The 30-m cells of the selected route are rendered to a virtual $10-\mathrm{m}$ grid which is used to approximate the center-line vertices of a vector version of the road, which are stored for later use. This detailed processing ensures that new roads connect to vertices of an existing road and provides a more realistic representation of simulated roads. Additional details on road creation are documented in the Energy Footprint Model Technical Document (https://my.usgs.gov/bitbucket/projects/WLCI/repos/energy_ footprint_model).

At the end of a simulation, simulated and baseline infrastructure are combined and output as time-stamped pad and road shapefiles. The same tabular attributes ingested for baseline pads and roads are stored annually for new pads and roads. These attributes are combined with shapefiles of baseline pads and roads and interim shapefiles of simulated pads (developed from the pad-pattern boundary coordinates) and roads (from the center-line vertices) to produce the final attributed shapefiles. These shapefiles can be subsequently used to analyze physical and ecological impacts. Because the model is stochastic, each simulation of a build-out design only represents one possible outcome. Simulation replicates of a buildout design are thus employed to bound plausible futures and to estimate an average future outcome. After generating shapefiles, the model initiates a replication of a build-out design starting with the initial landscape and repeating the fourstep procedures (Fig. 1) using a different random number seed. The number of replications is user-specified.

\section{Study Area}

I simulated alternative build-out scenarios for the $1090-\mathrm{km}^{2}$ Atlantic Rim Project Area (ARPA) in SW Wyoming (Fig. 2).
Although the ARPA has a unique shape, it contains land-use features and development restrictions common to regional energy-project areas. The ARPA has existing energy development, sage-grouse core areas which have special restrictions on development, sage-grouse leks and other conservation areas where surface disturbance is prohibited, and wild ungulate winter habitat and migration corridors. Additionally, $96 \%$ of the ARPA is sagebrush habitat which allows meaningful comparisons of sagebrush fragmentation among the scenarios. A conventional vertical-well design for the ARPA was approved in 2007 [36], but implementation was minimal by 2012 which is the vintage of key spatial information used in the model. I used a 5-km buffer around the ARPA in simulation assessments to reduce edge effects and to account for the influence of surrounding energy development on sagebrush fragmentation and wildlife impacts within the ARPA.

\section{Methods}

\subsection{Scenario Simulations}

I simulated 10 conventional and directional-drilling scenarios to evaluate tradeoffs in potential physical and ecological impacts. Scenario \#1 is the approved ARPA development plan and consists of 2000 vertical wells, one well per pad, and a bottom-hole spacing of 32.4 ha or eight wells per section [36]. The latter was industry's estimate of the reservoir area per well for economic recovery of natural gas. The remaining nine scenarios were contrived to experimentally evaluate the potential for using directional-drilling to reduce the amount of impacts to biophysical attributes. These scenarios spanned a gradient in directional-drilling frequency and in numbers of wells per pad that incrementally reduced the total number of pads, but all established 2000 wells using a 32.4-ha spacing (Table 1) to develop 648,000 ha (total bottom-hole area) of natural gas. An underlying assumption of this analysis is that the proven use of directional drilling for economic recovery of conventional and coal-bed natural gas [37] applies to the ARPA. Additionally, although there has been limited development in ARPA since 2007, there has been an increase in multi-well pads since 2010 (derived from [22]), indicating the potential to shift to new drilling methods in the future. Starting with the approved development plan (scenario 1, Table 1), I derived three experimental scenarios by a successive $50 \%$ reduction in the total number of pads and in the number of pads per section and a successive doubling of the number of wells per pad (scenarios 4, 7, and 10; Table 1). This provided a declining range in pad numbers from 2000 to 250 and an increase from one to eight wells per pad. Multi-well pads used directional bores for each well. Because the bottom-hole area of development per well remained constant, the increase in no. of wells per pad also reduces the number of pads per section 
Fig. 2 The Atlantic Rim Project Area (ARPA) and the 5-km buffer used in simulation assessments. The larger blue circles are leks inside of greater sage-grouse core areas (986-m no-surface occupancy (NSO) buffer); smaller blue circles are leks outside of core areas (465-m NSO buffer). Gray areas are closed to future oil and gas development or have NSO restrictions. Single-line generalizations of the six mule deer migration corridors assessed in this study are shown. Note that some pads and roads were established prior to the NSO restrictions

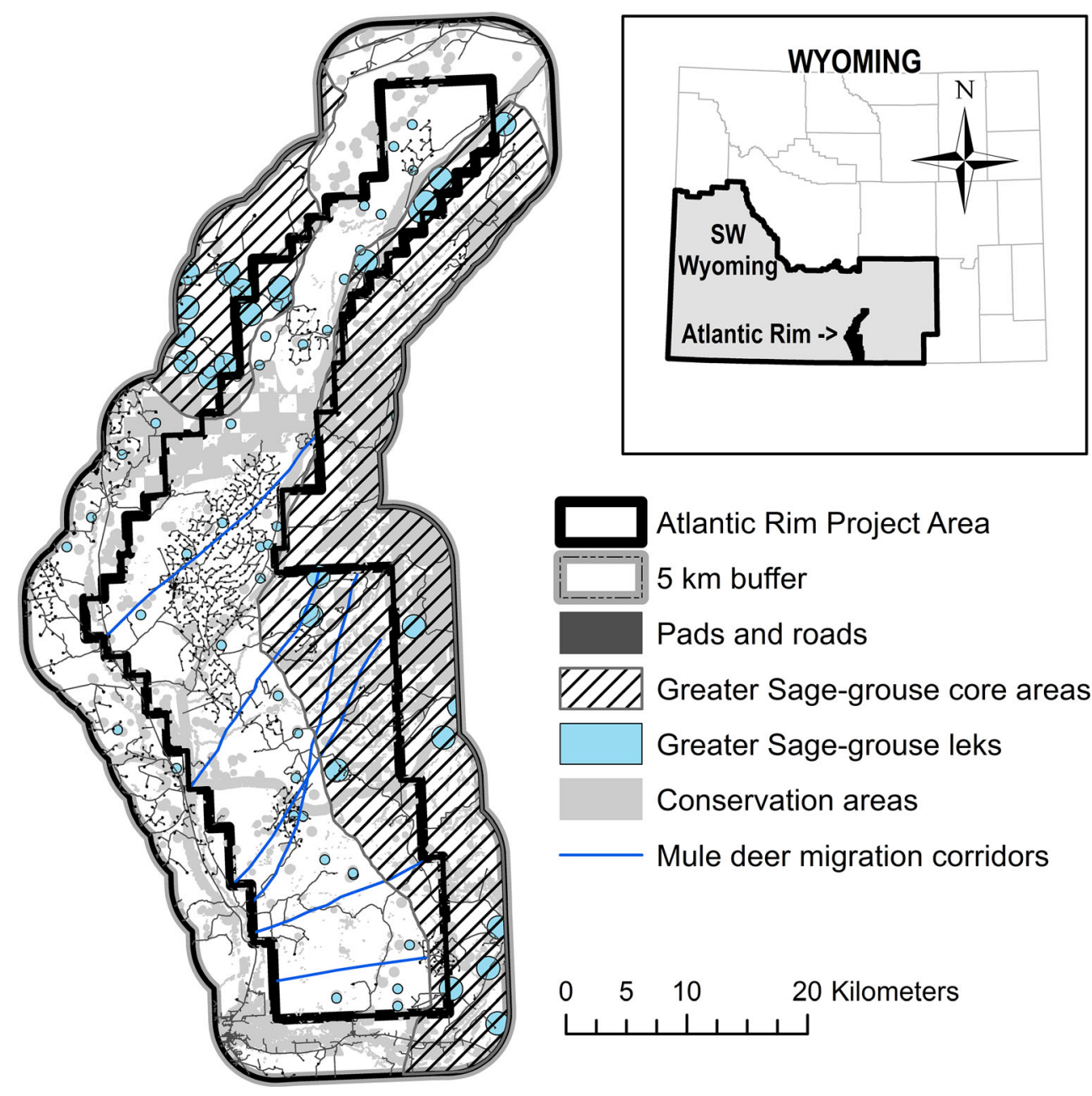

(Table 1). Scenario 10 used the maximum number of wells per pad and the fewest possible pads (250) to establish 2000 wells. Additional scenarios were generated to populate the experimental gradient in pad numbers. Scenarios 2 and 3 are extensions of scenario 1 and have two-thirds and one-half, respectively, of the 2000 wells allocated using the same one well/pad scheme as scenario 1. The remaining wells were allocated using twice this number and at half the pad density (Table 1). Thus, these scenarios distributed wells using two well-pad configurations until the number of pads per configuration was established. Similarly, scenarios 5 and 6 are extensions of scenario 4 , and scenarios 8 and 9 are extensions of scenario 7 (Table 1). Collectively, scenarios 1 to 10 provide a declining gradient in the total number of pads and in the number of pads per section, and an increasing gradient in numbers of directional wells per pad. In all scenarios, simulated development was only constrained by development restrictions; otherwise, the entire ARPA was available for development.

Simulations of each scenario started with the 2012 conditions of the ARPA landscape and the 5-km buffered area (hereafter baseline landscape) (Fig. 2). Abandoned wells and pads and roads connected only to abandoned pads were labeled as inactive and not used in impact assessments with a noted exception. Annual rate of development in the ARPA was approximately similar among scenarios over a 15-year development period. The 5-km buffer was developed using a nominal 200 wells distributed at one well per pad and eight wells per section. Forty replications of a scenario were sufficient to stabilize the coefficient of variation of analyzed measures. Random selection of section-selection methods was used in all simulations.

\subsection{Analyses}

\subsubsection{Physical Impacts}

I compared the extent of roads and the amount of surface disturbance produced by each scenario. At the end of a 15year simulation, I derived the number and length of individual simulated roads, the total length of roads, and surfacedisturbance area of simulated pads and roads. I graphically assessed the tendency for mean pad- and mean road-surface disturbance and numbers to change proportional to changes in 
Table 1 Simulated energy build-out scenarios

\begin{tabular}{|c|c|c|c|}
\hline Scenario no. & No. pads & $\begin{array}{l}\text { No. wells } \\
\text { per pad }\end{array}$ & $\begin{array}{l}\text { Pad density } \\
\text { (no. pads per section) }\end{array}$ \\
\hline 1 & 2000 & 1 & 8 \\
\hline \multirow[t]{2}{*}{2} & 1500 & 1 & 8 \\
\hline & $\frac{250}{1750}$ & 2 & 4 \\
\hline \multirow[t]{2}{*}{3} & 1000 & 1 & 8 \\
\hline & $\frac{500}{1500}$ & 2 & 4 \\
\hline 4 & 1000 & 2 & 4 \\
\hline \multirow[t]{2}{*}{5} & 750 & 2 & 4 \\
\hline & $\frac{125}{875}$ & 4 & 2 \\
\hline \multirow[t]{2}{*}{6} & 500 & 2 & 4 \\
\hline & $\frac{250}{750}$ & 4 & 2 \\
\hline 7 & 500 & 4 & 2 \\
\hline \multirow[t]{2}{*}{8} & 376 & 4 & 2 \\
\hline & $\frac{62}{438}$ & 8 & 1 \\
\hline \multirow[t]{2}{*}{9} & 250 & 4 & 2 \\
\hline & $\frac{125}{375}$ & 8 & 1 \\
\hline 10 & 250 & 8 & 1 \\
\hline
\end{tabular}

pad numbers. Scenario means were derived by averaging across simulation replicates.

\subsubsection{Wildlife Impacts}

I quantified the impacts of simulated scenarios on four wildlife species and taxa known to be affected by energy development. Minimizing the impairment of habitat functions for these species and taxa is a state-wide conservation emphasis [38] and aligns with performance goals of federal-estate energy developments [36]. For each, a variety of research studies document impacts of different measures of infrastructure (e.g., well density, total surface disturbance) at different spatial scales. For illustrative purposes, I used the results of just one study or synthesis to quantify impacts within the ARPA at the end of the 15-year development period. The same assessments were applied to the baseline landscape for reference. Assessments were performed using customized procedures that ingest output from the footprint model and also select ArcGIS [39] functions. Scenario means of impacts were derived by averaging across all simulation replications.

Sagebrush-Obligate Avian Species Range-wide population declines in the sage-grouse and sagebrush-obligate songbirds (hereafter songbirds) have been attributed to the loss and degradation of sagebrush habitat from conversion and altered fire regimes, and more recently from energy development $[1,7,40$, 41]. Reduction in numbers of male sage-grouse on traditional leks (indicator of population loss) is a well-documented impact of energy development [42]. I used relationships between threshold levels of infrastructure density and categories of lekattendance reduction derived from a synthesis of research studies [38] to quantify impacts to sage-grouse. A lek was assigned to the low/moderate reduction category (ca. $<27 \%$ reduction in attendance) if there were $0.01-1.23$ active pads $/ \mathrm{km}^{2}$ or $0.01-$ $3.11 \mathrm{ha} / \mathrm{km}^{2}$ of surface disturbance (active roads and pads) within $3.2 \mathrm{~km}$ of a lek, to the high/extreme reduction category (ca. $>41 \%$ reduction) if pad density or surface disturbance exceeded these values, and to a no-reduction category if there were no pads or surface disturbance within $3.2 \mathrm{~km}$ [38]. Because leks within SGCAs have larger NSO buffers (986 vs. $465 \mathrm{~m}$ for leks outside SGCAs), numbers of leks by attendancereduction category were analyzed separately for the 10 leks inside and the 32 leks outside SGCAs in the ARPA.

Breeding densities of songbirds have been shown to decline (36-57\%) within $100 \mathrm{~m}$ of active oil and gas roads in SW Wyoming [40]. I used the amount of songbird habitat within $100 \mathrm{~m}$ of road edges as a primary impact measure. A secondary measure was the amount of songbird habitat physically removed by all (incl. inactive) roads and pads. Songbird habitat $\left(525 \mathrm{~km}^{2}, 48 \%\right.$ of the ARPA) was delineated by applying the minimal values of sagebrush cover $(>11 \%)$ and shrub height $(>20 \mathrm{~cm})$ associated with breeding songbirds [40] to the 2006 Wyoming sagebrush-rangeland map [21]. Impacts to songbirds in the baseline-landscape assessment included the effects of development from 2006 to 2012.

Wild Ungulates Energy development has been shown to alter mule deer (Odocoileus hemionus) habitat use by reducing foraging near infrastructure and increasing use of lesspreferred habitats, with potential negative effects on energy balances of individuals [13, 43-46]. Habitat effectiveness for elk (Cervus elaphus) similarly is affected by human activity associated with transportation networks. A recent study in the ARPA [45] found mule deer to accelerate their rate of travel, reduce the use of stop-over forage areas, and alter their routes along seasonal migration corridors intersecting high-density energy development (defined as a road density of $1.92 \mathrm{~km} /$ $\mathrm{km}^{2}$ and a pad density of $2.82 / \mathrm{km}^{2}$ ). I used the total area of the six longest migration corridors in the ARPA with high-density development as a measure of impact. Designations of migration corridors available to this study were single-line generalizations of herd routes (https://wgfd.wyo.gov/Wildlife-inWyoming/Geospatial-Data/Big-Game-GIS-Data) and thus did not represent the actual area traversed by deer. I estimated migration area by buffering each side of the six corridor lines by $2.0 \mathrm{~km}$ which approximates the average width of the corridor areas in the ARPA mule deer study [45]. I derived active road and pad densities within a $1.0-\mathrm{km}$ 
Fig. 3 Examples of simulated energy infrastructure patterns within the ARPA at the end of the 15-year development period for the 10 scenarios (labeled at bottom of each map). Scenarios are described in Table 1.

Infrastructure in the 2012 landscape is included in all maps (see Fig. 2). Evident especially in the scenario \#1 map are the NSO areas (relatively large areas without development) and sagegrouse core areas (e.g., contrasting lower infrastructure density in the lower right-hand side of the ARPA - see Fig. 2)

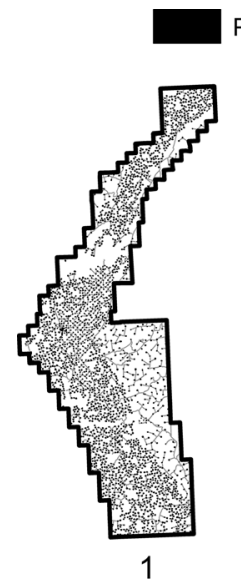

Pads Roads

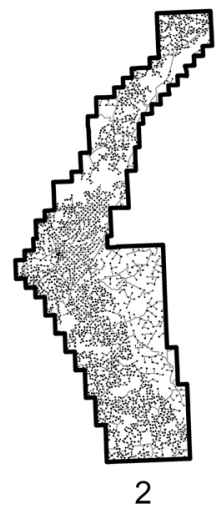

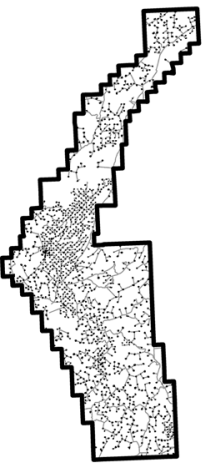

6
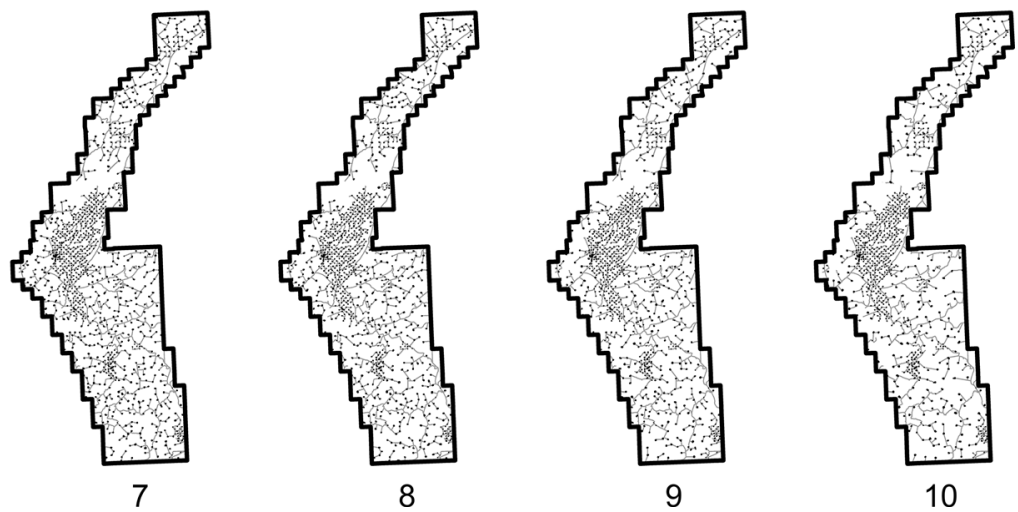

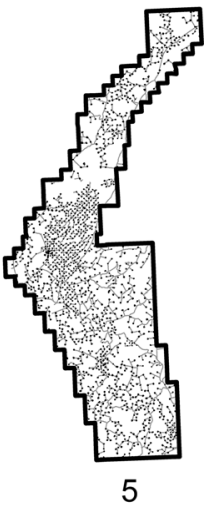

10 radius window located every $50 \mathrm{~m}$ within buffered areas (total non-overlapping area of $260 \mathrm{~km}^{2}, 24 \%$ of the ARPA). The percentage of windows with high-density development was converted to an aerial estimate of impacted migration habitat.

A road density $\geq 0.62 \mathrm{~km} / \mathrm{km}^{2}$ is an indicator of adversely affected habitat for elk in non-forested habitats [47, 48] and has been used to assess species' habitat effectiveness in SW Wyoming energy fields [49] and in oil and gas impact studies [28]. I used this threshold level to quantify road impacts to elk winter range $\left(1023 \mathrm{~km}^{2}, 93 \%\right.$ of the ARPA - https://wgfd. wyo.gov/Wildlife-in-Wyoming/Geospatial-Data/Big-GameGIS-Data). I derived active road density within a $2.0-\mathrm{km}$ radius window located every $100 \mathrm{~m}$ in winter range within the ARPA boundary, then converted the percentage of windows with a road density equal to or greater than the threshold value to an aerial estimate of impacted winter range.

\subsubsection{Fragmentation of Sagebrush Core Area}

I compared the amount of sagebrush core-area habitat for different effect-zone distances among the 10 scenarios. Effect zone is the area of influence of human infrastructure that extends beyond the physical footprint, and core habitat is the remaining area [50]. The size of an effect zone varies with the human-mediated influence and the effected habitat or species. The effect-zone distance of different energyinfrastructure features (e.g., wells, pads) can range from $100 \mathrm{~m}$ [40] to $500 \mathrm{~m} \mathrm{[7]} \mathrm{for} \mathrm{songbirds,} 600+\mathrm{m}$ for exoticplant invasion [51], and $8.5 \mathrm{~km} \mathrm{[52]} \mathrm{to} 20 \mathrm{~km} \mathrm{[53]} \mathrm{for} \mathrm{sage-}$ grouse. In general, energy-development designs that result in more core-area habitat at multiple effect-zone distances have a greater potential to support habitat functions for a variety of species. Here I used a gradient of distances for a generalized assessment of sagebrush core-area patterns and fragmentation. I overlaid the ARPA sagebrush map (derived from the 2006 Wyoming sagebrush-rangeland map [21]) with maps of the baseline plus simulated landscapes and generated effect zones from 0.0 to $1.0 \mathrm{~km}$ in $100-\mathrm{m}$ intervals by buffering from edges of roads and pads by the interval distance. Sagebrush overlapping buffered areas was removed to produce core-area maps for each effect zone. In the 0-m effect zone, sagebrush was removed only where it overlapped pads and roads and thus represented the direct physical effect of infrastructure. For each core-area map, I derived the total amount of core area. I also aggregated core area into patches, where individual patches consisted of spatially connected core area. Fragmented landscapes are typified by remnant, small patches. Conversely, landscapes with relatively large patches 
Fig. 4 Measures of simulated pads and roads at the end of the simulated 15-year development period for the 10 scenarios. No. of pads decreases from left to right on the $x$-axis to emphasize declining trends. a Mean surfacedisturbance area of new pads and roads, and total (pads + roads), $\mathbf{b}$ mean number and total length of new roads, and lengths of individual roads; a polynomial regression line shows the curvilinear trend in mean road length. The proportional reference lines show expected values if the decline in pad and in road surface disturbance (a) and in the number and total length of new roads (b) is proportional to changes in the number of simulated pads. Standard deviations are $<1.0 \%$ of means and appear as horizontal lines through the center of symbols

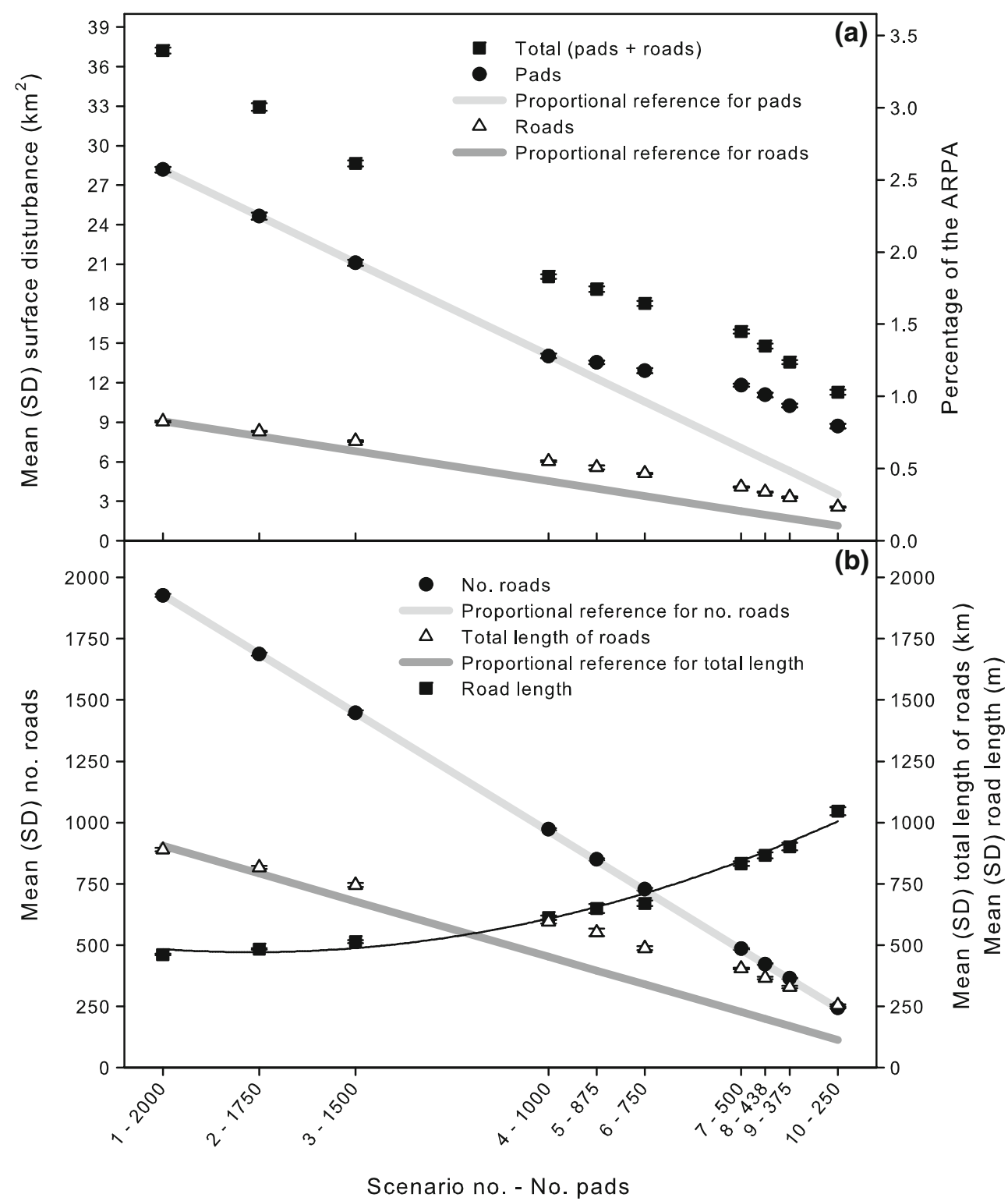

are indicative of less fragmented landscapes. I treated the largest patch size of core area as a generalized indicator of fragmentation. Both total core area and largest patch will decrease with increasing effect-zone distances, although the amount or rate of decrease can vary with initial amount of core area. I derived the mean rate of decrease in total core area and of largest patch size across the effect-zone gradient for each scenario as a comparable measure of habitat loss and fragmentation, respectively. Relatively lower rates of decline indicate lower habitat loss and fragmentation, or conversely, a higher potential to conserve non-fragmented habitat. I generated estimates of the mean rate (i.e., slope) of decline for lntransformed total core area and for ln-transformed largest patch size over the $0-700 \mathrm{~m}$ effect-zone gradient [54]. Natural-log transformation linearized curvilinear trends. Slope estimates were limited to the $0-700 \mathrm{~m}$ gradient because of asymptotic trends prevalent in $\geq 800$-m effect zones which produced a noticeable bias even in ln-transformed slopes. I translated mean slope values to percent decline per 100-m effect-zone interval to enhance interpretation and comparisons. Similar slope estimates were generated for the 2012 baseline landscape. Because of the vintage of the rangelandsagebrush map, baseline measures included the effects of energy development since 2006.

\section{Results}

\subsection{Landscape Pattern and Physical Footprint}

Landscape patterns of simulated energy infrastructure noticeably differed among the 10 scenarios (Fig. 3). Most visually 

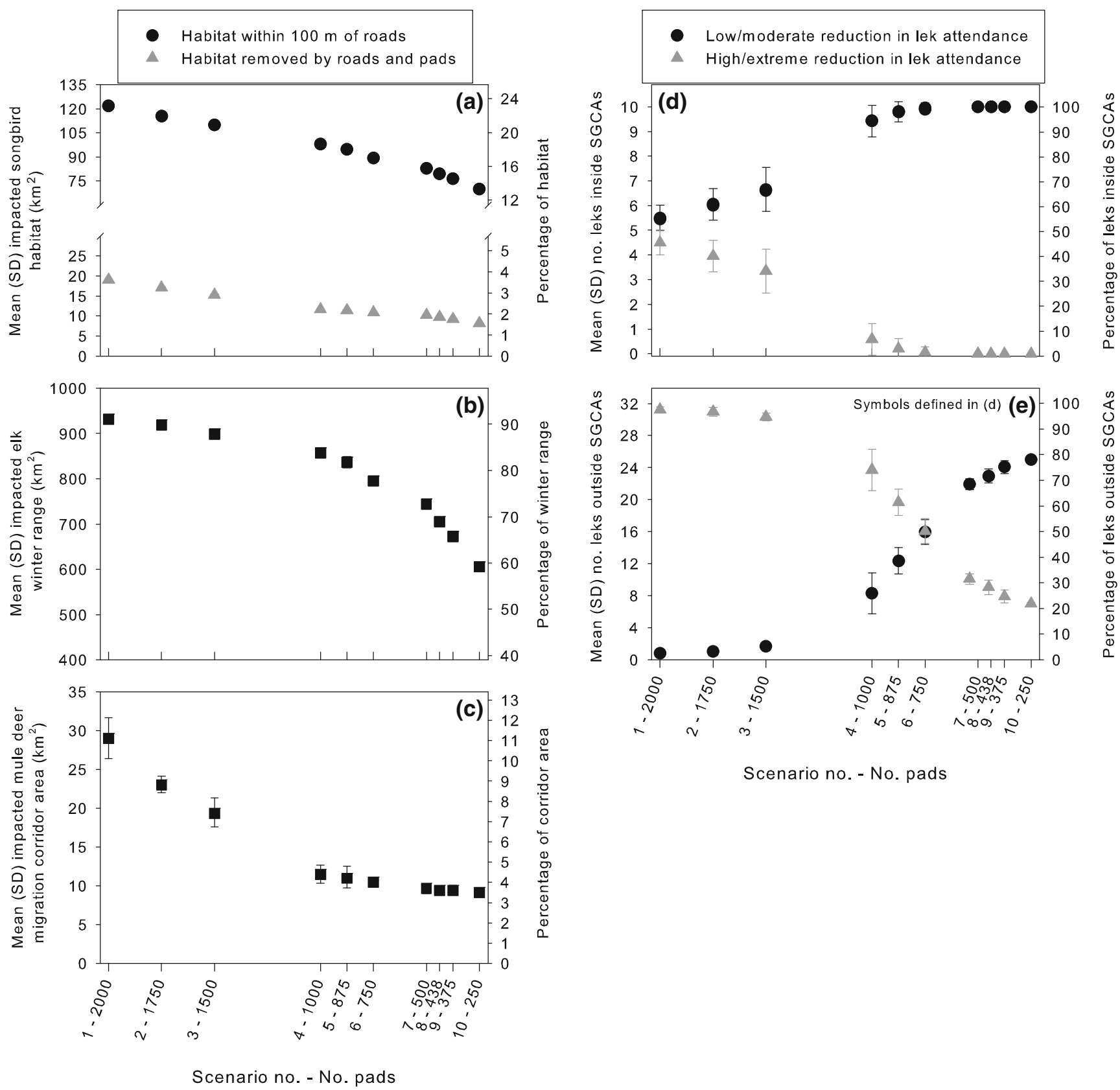

Scenario no. - No. pads

Fig. 5 Wildlife impacts at the end of the simulated 15-year development period for the 10 scenarios. a Extent of sagebrush-obligate songbird habitat within $100 \mathrm{~m}$ of roads and amount removed by the physical footprint of infrastructure, $\mathbf{b}$ area of elk winter range impacted by roads (road density $\geq 0.62 \mathrm{~km} / \mathrm{km}^{2}$ ), $\mathbf{c}$ area of mule deer migration corridors with

apparent is the decline in the extent and complexity of the road network and in overall infrastructure density with increasing use of directional drilling and higher numbers of wells per pad. Constancy in numbers (2000) and bottom-hole spacing of wells (eight per section), however, imposed a similar general pattern of development among scenarios. On average, the same number of sections (250) was developed. Given this and the extent of development restrictions (Fig. 2), new development was dispersed in all scenarios (Fig. 3). That is, high-density infrastructure (see text), $\mathbf{d}$ no. of leks inside sage-grouse core areas (SGCAs) predicted to experience low/moderate and high/extreme reduction in lek attendance, $\mathbf{e}$ same as $\mathbf{d}$ but for leks outside SGCAs. Most standard deviations are $<1 \%$ of means and obscured by symbols

development was not clustered or excluded from regions of the ARPA as pad numbers decreased. The clustering evident in the center of the ARPA in Fig. 3 (especially scenarios 6-10) is the extant development in 2012 (compare with Fig. 2).

Scenario means of pad and road surface-disturbance area decreased with decreasing pad numbers. The decline in disturbance area, however, was not linearly related to changes in pad numbers (Fig. 4). Mean surface disturbance of pads decreased proportional to pad numbers until scenario 5 (875 
Fig. 6 Trends in the fragmentation of sagebrush core area with increasing effect zone for the baseline landscape and the 10 scenarios at the end of the 15 year development period. a Mean total sagebrush core area. b Mean largest sagebrush core-area patch. Most standard deviations are $<1 \%$ of means and largely obscured by symbols
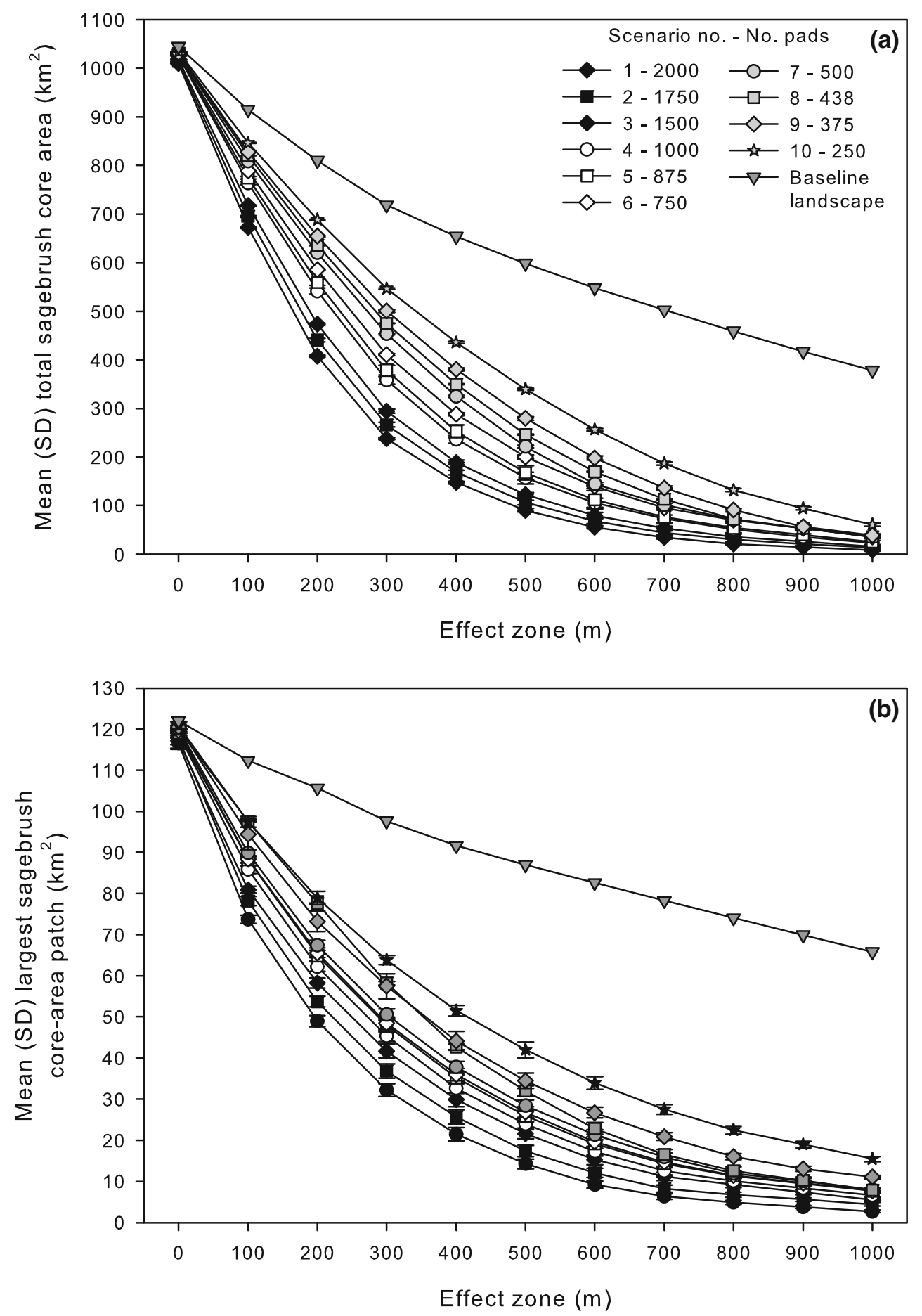

pads) where mean pad size increased to accommodate four wells per pad (Fig. 4a). Mean road disturbance decreased at a rate less than proportional to changes in pad numbers (Fig. 4a). Across the declining gradient in pad numbers, the number of new roads decreased proportionally but the decline in total road length was lower than proportional due to a curvilinear increase in mean road length (Fig. 4b), which collectively accounted for the trend in road surface disturbance (Fig. 4a).
Overall, these results show that as fewer pads were used for the same level of energy production the total amount of surface disturbance declined but disturbance area increased on a per pad basis. For instance, mean total surface disturbance was 37.2 (3.4\% of the ARPA), $20.3(1.9 \%)$, and $11.5 \mathrm{~km}^{2}(1.0 \%)$ in scenarios with 2000, 1000, and 250 pads, respectively (Fig. 4a); mean total surface disturbance per pad was $0.018,0.02$, and $0.046 \mathrm{~km}^{2}$, respectively. 
Table 2 Natural log-linear model estimates of the rate of decline in total sagebrush core area and in the largest core-area patch with increasing effect zone $(0-700 \mathrm{~m})$. Mean slope values were translated to percent decline per $100 \mathrm{~m}$ increase in effect zone to facilitate interpretation and comparisons. For reference, the percent decline per 100-m interval in total core area and largest patch size in the baseline landscape was 9.8 and 5.8, respectively

\begin{tabular}{llllll}
\hline Scenario (no. pads) & \multicolumn{2}{l}{ Total sagebrush core area } & & \multicolumn{2}{l}{ Largest sagebrush core-area patch } \\
\cline { 2 - 3 } \cline { 5 - 6 } & Mean (se) slope & Percent decline per 100-m interval & Mean (se) slope & Percent decline per 100-m interval \\
\cline { 2 - 3 } $1(2000)$ & $-0.00491(0.0000115)$ & 38.7 & $-0.00416(0.0000171)$ & 34.0 \\
$2(1750)$ & $-0.00456(0.0000135)$ & 36.7 & $-0.00378(0.0000161)$ & 31.5 \\
$3(1500)$ & $-0.00431(0.0000125)$ & 35.1 & $-0.00335(0.0000134)$ & 28.5 \\
$4(1000)$ & $-0.00388(0.0000170)$ & 32.1 & $-0.00322(0.0000109)$ & 27.5 \\
$5(875)$ & $-0.00382(0.0000273)$ & 31.7 & $-0.00305(0.0000102)$ & 26.3 \\
$6(750)$ & $-0.00345(0.0000111)$ & 29.2 & $-0.00300(0.0000104)$ & 25.9 \\
$7(500)$ & $-0.00337(0.0000174)$ & 28.6 & $-0.00289(0.0000095)$ & 25.1 \\
$8(438)$ & $-0.00316(0.0000167)$ & 27.1 & $-0.00258(0.0000108)$ & 22.7 \\
$9(375)$ & $-0.00288(0.0000148)$ & 25.0 & $-0.00251(0.0000107)$ & 22.1 \\
$10(250)$ & $-0.00242(0.0000104)$ & 21.5 & $-0.00211(0.0000100)$ & 19.0 \\
\end{tabular}

\subsection{Wildlife Impacts}

Decreasing pad numbers decreased impacts to wildlife, but the magnitude and trends of impacts varied among the four species and taxa. The amount of songbird habitat within $100 \mathrm{~m}$ of roads declined with decreasing pad numbers (Fig. 5a). Across the 2000 to 1000-pad scenarios, average area of impacted habitat declined from $121 \mathrm{~km}^{2}$ (23\% of total habitat) to $98 \mathrm{~km}^{2}$ (19\%) or a $2 \%$ rate of decline. Further reduction in pad numbers $(875$ 250 pads) resulted in a $4 \%$ rate of decline in amount of impacted habitat. Mean impacted habitat in the 250-pad scenario was $70 \mathrm{~km}^{2}$ (13\%) which was $24 \mathrm{~km}^{2}$ more than in the baseline landscape. Mean area of songbird habitat removed by infrastructure also declined from 19 to $8 \mathrm{~km}^{2}$ over the declining gradient in pad numbers, with the steepest rate of decline (0.8\%) between the 500- and 250-pad scenarios (Fig. 5a). Amount of removed habitat in the 250-pad scenario was $5 \mathrm{~km}^{2}$ higher than baseline conditions. Area of impacted elk winter range declined with decreasing pad numbers. Trends were similar to those for songbird habitat near roads, but the magnitude of impact was much greater and a threshold response was more pronounced (Fig. $5 b$ ). A mean of $931 \mathrm{~km}^{2}$ or $91 \%$ of winter range was scored as impacted in the 2000-pad scenario. Using only directional well bores and half this number of pads reduced this amount to $857 \mathrm{~km}^{2}(84 \%)$ or an $8 \%$ rate of decline. From 875 to 250 pads, the amount of affected habitat sharply declined (36\% rate of decline). Mean amount of impacted habitat in the 250-pad scenario was $605 \mathrm{~km}^{2}(59 \%)$ which was three times the amount in the baseline landscape.

The maximum impact to mule deer corridor habitat occurred in the high-density scenario (2000 pads), but impacted area was only $29 \mathrm{~km}^{2}$ or $11 \%$ of total corridor area (Fig. $5 \mathrm{c}$ ). Across the 2000 to 1000-pad gradient, mean affected area decreased sharply to $11 \mathrm{~km}^{2}(4 \%)$. Infrastructure densities produced by scenarios with $\leq 875$ pads resulted in slightly more to similar amount of high-density development within corridors $\left(9-11 \mathrm{~km}^{2}\right)$ as the baseline landscape $\left(9 \mathrm{~km}^{2}\right)$ where three migration corridors overlapped existing energy fields. Scenarios with $\leq 750$ pads effectively resulted in similar levels of impact.

Reducing the number of pads increased the number of leks scored in the low/moderate reduction category, but trends varied with lek location (Fig. 5d-e). For leks within SGCAs, reducing pad numbers from 2000 to 1000 resulted in an increase in the mean number (5.6 to 9.5) ascribed to the low/ moderate category (Fig. 5 d). Scenarios with $\leq 875$ pads effectively had lower but similar amounts of surface disturbance within $3.2 \mathrm{~km}$ of leks, resulting in the scoring of all leks to the low/moderate attendance-reduction category which mirrored the initial landscape (Fig. 5d). Trends for leks outside SGCAs reflected the smaller NSO buffer. On average, only 1-2 leks were scored in the low/moderate category in scenarios with $\geq 1500$ pads (Fig. 5e). Across the $1000-500$ pad scenarios, the mean number in this category increased to 24 leks. Further reduction in pad numbers resulted in only slightly more leks ascribed to this category but mean numbers were similar between adjacent scenarios (Fig. 5e). For scenarios with $\leq 375$ pads and the baseline landscape, about $78 \%$ of the 32 leks was predicted to have low/moderate reduction in attendance and the remaining leks were ascribed to the high/extreme category. Leks in all replications had at least a pad or surface disturbance within $3.2 \mathrm{~km}$; thus, none were assigned to the noreduction category.

\subsection{Fragmentation of Sagebrush Core Area}

Both pad numbers and effect-zone distance influenced the extent and pattern of sagebrush core area. The physical 
Fig. 7 Examples of sagebrush core-area patterns with increasing effect-zone distances for four simulated scenarios at the end of the 15-year development period. Columns are different effect zones (defined at the top) and rows are different scenarios (defined along right-hand side)
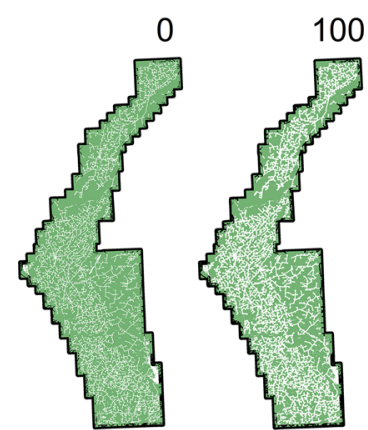

00

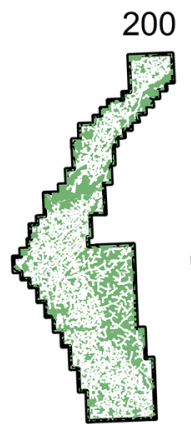

Effect distance $(\mathrm{m})$

200
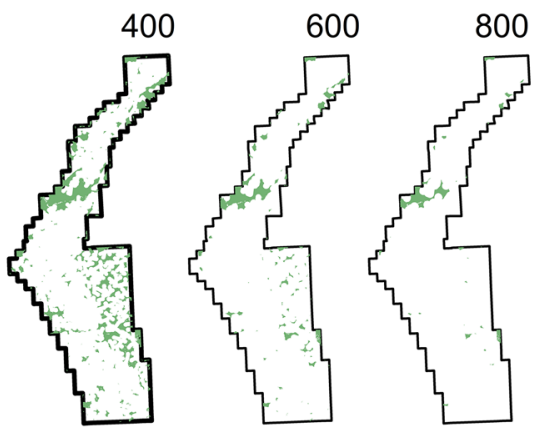

Scenario 1

(2000 pads)
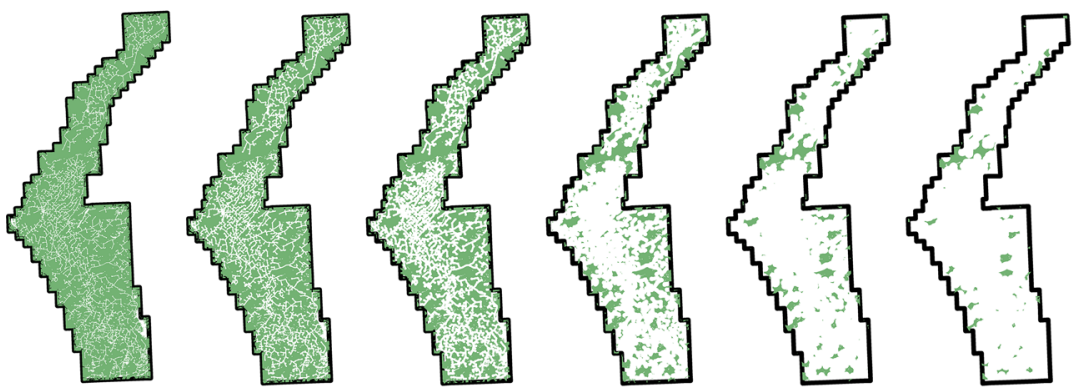

Scenario 4

(1000 pads)
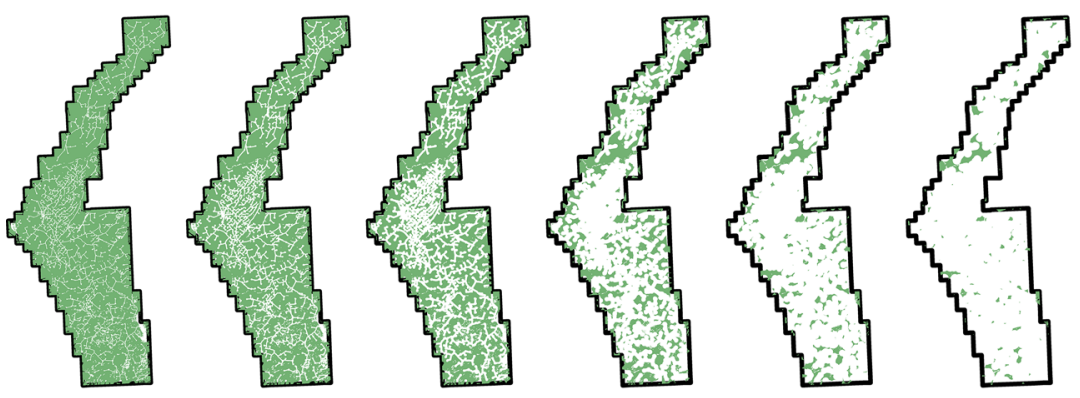

Scenario 7

(500 pads)
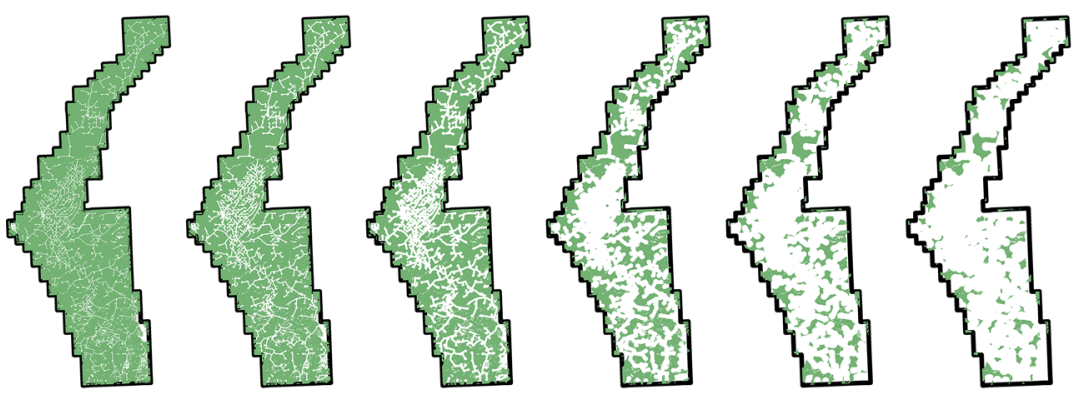

Scenario 10

(250 pads)

051020 Kilometers

سلس 
scenarios differed by a factor of about three for total core area $\left(160-465 \mathrm{~km}^{2}\right.$, respectively) and about 2.3 for largest patch size (21-50 km², respectively; Fig. 6). Core-area maps visually illustrate how core-area patterns varied with fragmentation rates (Fig. 7). In higher-density scenarios, core area in the smaller effect zones (100-200 m) was noticeably eliminated from large contiguous areas of the landscape with the remaining sagebrush splintered into numerous, smaller patches (e.g., Fig. 7, 2000-pad scenario). This contrasts with the tendency for these effect zones in lower-density designs to effectively dissect sagebrush into fewer but larger patches throughout the ARPA (e.g., Fig. 7, 250-pad scenario). These general patterns prevailed with increasing distance until effect zones started to saturate the landscape. At distances $>600-700 \mathrm{~m}$, scenario means began to converge (Fig. 6) as the extent of core area became limited (Fig. 7). Relative to the baseline landscape, adding as few as 250 pads to the landscape substantially increased fragmentation of sagebrush core area for effect zones $\geq 200$ m (Fig. 6).

\section{Discussion and Conclusions}

Results of this study illustrate the potential for directional drilling technology to decrease surface disturbance of energy infrastructure compared to conventional vertical wells for the same level of gas extraction. The incremental increase in the number of directional well bores and multi-well pads reduced pad numbers and decreased mean total surface disturbance even for relatively small differences in pad numbers (e.g., 438 vs. 375; Fig. 4). Compared to using only vertical wells, maximizing the use of directional drilling by locating one pad with eight wells in each section required 1750 fewer pads and resulted in one-third the amount of surface disturbance (scenarios 1 vs. 10; Fig. 4a). Results also highlight that trends in surface disturbance may not be linear and proportional to changes in energy-infrastructure density. A lower than proportional relationship between disturbance and numbers of pads is expected where fewer but larger pads are used to accommodate a fixed total number of wells (Fig. 4a). In this study, decreasing pad numbers required roads, on average, to be longer to connect new pads to the existing transportation network and resulted in lower than proportional changes in road surface disturbance (Fig. 4a). Factors influencing this trend were the low road density in the initial ARPA landscape (Fig. 2) and the dispersed pattern of new development (Fig. 3). The relationship found here between road area and pad numbers is not universal and expected to differ among energy fields and build-out patterns. In particular, lengths of new roads in areas with an existing high-density road network are likely to be invariant of pad numbers which would result in a linear and proportional relationship between road area and pad densities. Federal planning documents use expected amounts of pad and road surface disturbance estimated from analog designs on the landscape or analytically to contrast alternative build-out designs [36]. However, limited directional-drilling examples on the current landscape and uncertainty in actual infrastructure placement relative to a temporally evolving road network influence the accuracy of these estimates for new-technology approaches. A benefit of the footprint model is that it explicitly considers this uncertainty in bounding estimates of new-technology infrastructure disturbance and thus provides more credible insights into how physical impacts may differ among alternative designs and energy fields.

This study also illustrates how reducing infrastructure density with directional drilling technology can reduce ecological impacts. Impacts to species and taxa and sagebrush core-area fragmentation declined by replacing vertical with directional well bores and increasing well numbers per pad, although the amount of decline was mediated by the spatial extent of habitat and initial landscape conditions. Spatially extensive habitats had a greater chance of overlapping and being affected by energy development. For the extensive songbird, elk, and sagebrush habitats (48-96\% of the ARPA), impacts declined with declining infrastructure density (Figs. 5a, b and 6) (with exceptions for core-area fragmentation; Fig. 6b) even between scenarios that only differed by $1.1 \mathrm{~km}^{2}$ in mean total surface disturbance (e.g., scenarios 7 and 8; Fig. 4). In the lowestdensity scenario (250 pads), quantified impacts exceeded baseline levels indicating that even a low amount of development can have measurable effects on spatially extensive habitats. For limited or spatially restricted habitats, the benefits of reducing infrastructure density reached a maximum where the patterns of development added nominal to no additional disturbance beyond baseline conditions, or at least where the quantitative relationships used to assess impact were insensitive to the added infrastructure. This occurred for mule deer migration habitat in the 750-pad scenario (Fig. 5c) and in different scenarios for leks inside (875-pad scenario; Fig. 5d) and outside (375-pad scenario; Fig. 5e) SGCAs. These results highlight a practical consideration in that the amount and pattern of species' and sagebrush habitat determine the extent of design impacts and the ability to reduce impacts with smaller energy footprints. Because of this, oil and gas recovery options with high conservation potential within an energy field may have lower potential in other fields. Ideally, the efficacy of build-out designs for individual species and native habitat should be evaluated in the context of individual project areas.

Modeled impact measures provide critical decision-making information for assessing the performance of build-out designs relative to conservation-management goals. Assessments provide quantitative estimates of both the magnitude and relative difference in multi-resource impacts among designs. To assess the tradeoffs among designs, decision-makers may attribute importance to measures of 
surface disturbance, wildlife impacts, and habitat fragmentation based on local conservation needs and management objectives, or more generally, acceptable limits of physical and ecological impacts in the context of regional conservation goals. Importance measures can be combined using approaches such as a multi-attribute utility function [55] to score designs relative to management goals. In this study, for example, ascribing high importance to minimizing impacts to sagegrouse would identify directional-well designs with $\leq 375$ pads as the most desirable which also have relatively low impacts on other species (Fig. 5). However, if land managers were largely concerned with the conservation of mule deer corridors within ARPA, a directional-well design with as many as $750-875$ pads may be sufficient to achieve this goal (Fig. 5c), depending on acceptable levels of impact to other species and sagebrush habitat.

Additionally, practical decision-making requires contrasting the conservation benefits of designs with development costs. Drilling costs per unit length of directional wells can be 15$30 \%$ higher than vertical wells [56], but extensive use of directional well bores can substantially reduce overall road and pad construction costs, and potentially increase production rates and economic return [57]. Alternatively, directional drilling in formations such as low-production tight-gas sands requires additional effort and costs (e.g., longer wells with extensive fracking), and the economic viability of this type of recovery is highly dependent on market-price forecasts of natural gas. Estimating net-cost of build-out options is beyond the scope of the footprint model, but estimates may be acquired from a working knowledge of energy-development costs or discussions with oil and gas operators. Designs selected using costbenefit criteria may be less than optimal in terms of wildlife and habitat conservation, but more feasible or favorable for actual implementation [26]. In such cases, results of impact assessments can additionally help identify species' risks and mitigation requirements for selected designs.

The footprint model provides the ability to evaluate the conservation potential of new-technology recovery options, but has notable limitations. The model does not simulate the full suite of infrastructure associated with oil and gas development, such as injector wells, pipelines, compressor pads, produced-water retention ponds, water storage areas for hydrologic fracking, and power lines. Although pads and roads are dominant sources of surface disturbance, these additional infrastructure features contribute at least somewhat to the physical footprint of a build-out design and have additional impacts on wildlife $[12,58]$. Model impact results are thus conservative estimates of infrastructure densities and effects. Wildlife avoidance of energy infrastructure is attributed to various factors, but human activity is a prominent reason $[42,59]$. The model does not estimate human activity, such as road-traffic volume or visitation frequency of pads, which can vary with the age and density of energy fields. All roads and pads are assumed to have equal activity levels which may over- or underestimate impacts depending on field age and density. Similarly, energy-development effects on wildlife typically are based on measures of active infrastructure (pads with producing wells, roads connecting to active pads). All active wells, pads, and roads in the baseline landscape and all simulated infrastructure are assumed active for the duration of a simulation. Historically, 30-35 years is the life span of a producing well in SW Wyoming, although newly drilled wells may be dry and immediately abandoned [60], and wells and pads may be abandoned when declining production or market prices minimize economic recovery. Where pads and roads are permanently abandoned on federal mineral estates, restoration is required within a specified time period [61]. The current model assumption of continuous well production and road use likely has nominal effects on results for short-duration simulations of new fields. However, for simulations of expanding energy fields with older wells and longer-term simulations, enhancements to emulate infrastructure abandonment and restoration are essential for reliable results.

Expanding modeled impacts to include effects on species' densities and productivity and other species of management concern are additional enhancements to increase the breadth and relevance of build-out assessments. From research findings in Wyoming, additions include relationships between well densities and discrete estimates of sage-grouse lek attendance rates [27, 41] and rates of decline in breeding densities of individual songbird species [7], and between energymediated habitat loss and songbird nest success rates [62]. Estimating actual population loss requires knowing population densities over the duration of a development effort which are difficult to reliably estimate. Rate estimates, however, provide relative and comparable indicators of how species' numbers may be impacted by energy-development options. Including impacts on habitat functions for all big-game species [38] broadens the spectrum of key species considered in assessments. Additionally, including energy development effects on exotic-plant invasion [51] offers a unique ability to evaluate impacts on native-habitat integrity.

Implementing oil and gas recovery designs that minimize physical and ecological impacts will be increasingly important to conserve native habitat and wildlife populations in SW Wyoming. From a practical stand point, build-out strategies will always be constrained by the geological properties of oil and gas plays (e.g., formations only accessible with vertical wells) and initially conceived by oil and gas operators based on market forecasts and anticipated economic recovery. However, planners and decision-makers of federal mineral estates have the opportunity to promote consideration of designs with enhanced conservation potential in the planning phases of new developments. With the addition of enhancements noted above, research applications of the energyfootprint framework in existing and proposed SW Wyoming 
energy fields can begin to document species' and habitat impacts for a wide range of conventional and new-technology combinations, well-pad configurations, and spacings. Results of these applications can help planners and decision-makers identify alternative designs for discussion with operators in the pre-decisional phase of an energy project. Plausible alternatives based on cost-benefit criteria, engineering constraints, and other factors may be adopted for implementation, encourage modifications to initially proposed designs, or at least be included in approved development plans as options for operators as a field is developed. For existing conventional developments that have stalled due to changes in market prices or in conservation regulations, simulation results also may motivate re-evaluation of previous designs and help guide future shifts to lower-impact build-out strategies.

Acknowledgements I thank N. Brunner and R. Taylor and for their assistance in the preparation of digital maps, S. Hawkins for her insights on oil and gas drilling technologies, and D. Shinneman, J. Diffendorfer, and the Editor-in-Chief of the journal for their constructive comments that improved the original manuscript. Funding for this study was provided by the USGS Land Change Science program and the Wyoming Landscape Conservation Initiative (USGS Ecosystems Mission Area). Any use of trade or product names is for descriptive purposes only and does not imply endorsement by the US Government.

Open Access This article is distributed under the terms of the Creative Commons Attribution 4.0 International License (http:// creativecommons.org/licenses/by/4.0/), which permits unrestricted use, distribution, and reproduction in any medium, provided you give appropriate credit to the original author(s) and the source, provide a link to the Creative Commons license, and indicate if changes were made.

\section{References}

1. Naugle, D. E., Doherty, K. E., Walker, B. L., Holloran, M. J., \& Copeland, H. E. (2011). Energy development and greater sagegrouse. In S. T. Knick \& J. W. Connelly (Eds.), Greater sagegrouse: ecology and conservation of a landscape species and its habitats. Studies in avian biology series (Vol. 38, pp. 489-505). Berkeley, California: University of California Press.

2. Braun, C. E., Baker, M. F., Eng, R. L., Gashwiler, J. S., \& Schroeder, M. H. (1976). Conservation committee report on effects of alteration of sagebrush communities on the associated avifauna. Wilson Bulletin, 88(1), 165-171.

3. Crawford, J. A., Olson, R. A., West, N. E., Mosley, J. C., Schroeder, M. A., Whitson, T. D., Miller, R. F., Gregg, M. A., \& Boyd, C. S. (2004). Ecology and management of sage-grouse and sage-grouse habitat. Journal of Range Management, 57(1), 2-19.

4. Connelly, J. W., Knick, S. T., Schroeder, M. A., \& Stiver, S. J. (2004). Conservation assessment of greater sage-grouse and sagebrush habitats. Cheyenne, Wyoming: Western Association of Fish and Wildlife Agencies.

5. Beck, J. L., \& Mitchell, D. L. (2000). Influences of livestock grazing on sage grouse habitat. Wildlife Society Bulletin, 28(4), 9931002.

6. Connelly, J. W., \& Braun, C. E. (1997). Long-term changes in sage grouse Centrocercus urophasianus populations in western North America. Wildlife Biology, 3(2), 229-234.
7. Gilbert, M. M., \& Chalfoun, A. D. (2011). Energy development affects populations of sagebrush songbirds in Wyoming. Journal of Wildlife Management, 75(4), 816-824.

8. Knick, S. T., Dobkin, D. S., Rotenberry, J. T., Schroeder, M. A., Vander Haegen, W. M., van Riper, I. I. I., \& C. (2003). Teetering on the edge or too late? Conservation and research issues for avifuana of sagebrush habitats. Condor, 105(4), 611-634.

9. Steenhof, K., Kochert, M. N., \& Roppe, J. A. (1993). Nesting by raptors and common ravens on electrical transmission line towers. Journal of Wildlife Management, 57(2), 271-281.

10. Taylor, R. L., Tack, J. D., Naugle, D. E., \& Mills, L. S. (2013). Combined effects of energy development and disease on greater sage-grouse. PloS One, 8(8), 1-10.

11. Walston, L. J., Cantwell, B. L., \& Krummel, J. R. (2009). Quantifying spatiotemporal changes in a sagebrush ecosystem in relation to energy development. Ecography, 32(6), 943-952.

12. Doherty, K. E., Naugle, D. E., Walker, B. L., \& Graham, J. M. (2008). Greater sage-grouse winter habitat selection and energy development. Journal of Wildlife Management, 72(1), 187-195.

13. Sawyer, H., Kauffman, M. J., \& Nielson, R. M. (2009). Influence of well pad activity on winter habitat selection patterns of mule deer. Journal of Wildlife Management, 73(7), 1052-1061.

14. Holloran, M. J., Kaiser, R. C., \& Hubert, W. A. (2010). Yearling greater sage-grouse response to energy development in Wyoming. Journal of Wildlife Management, 74(1), 65-72.

15. US Energy Information Administration (EIA). (2014). Annual energy outlook 2014 with projections to 2040. Office of Integrated and International Energy Analysis. Washington, DC: U.S. Department of Energy.

16. INGAA Foundation. (2014). North American midstream infrastructure through 2035: Capitalizing on our energy abundance. http:// www.ingaa.org/Foundation/Foundation-Reports/Studies/14904/ 14889.aspx. Accessed 5 April 2014.

17. Wyoming State Geological Survey. (2015). Wyoming's oil and gas resources: summary report, February 2015. http://www.wsgs.wyo. gov/products/2015-oil-gas-summary.pdf. Accessed 10 March 2015.

18. US Departments of the Interior, Agriculture, and Energy. (2008). Inventory of onshore federal oil and natural gas resources and restrictions to their development: phase III inventory- onshore United States. BLM/WO/GI-03/002+3100/REV08. http://www.blm.gov/ epca. Accessed 10 May 2013.

19. Sawyer, H., Lindzey, F., \& McWhirter, D. (2005). Mule deer and pronghorn migration in western Wyoming. Wildlife Society Bulletin, 33(4), 1266-1273.

20. Bowen, Z. H., Aldridge, C. L., Anderson, P. J., Chong, G. W., Drummond, M. A., et al. (2009). U.S. Geological Survey science strategy for the Wyoming Landscape Conservation Initiative. U.S. Geological Survey Scientific Investigations Report 2008-5195, p. 26 http://pubs.usgs.gov/sir/2008/5195. Accessed 10 February 2013.

21. Homer, C. G., Aldridge, C. L., Meyer, D. K., \& Schell, S. J. (2012). Multi-scale remote sensing sagebrush characterization with regression trees over Wyoming, USA: laying a foundation for monitoring. International Journal of Applied Earth Observation and Geoinformation, 14, 233-244.

22. Biewick, L. R. H., \& Wilson, A. B. (2014). Energy map of Southwestern Wyoming, part b-oil and gas, oil shale, uranium, and solar. U.S. Geological Survey Data Series 843. http://pubs. usgs.gov/ds/843. Accessed 2 December 2014.

23. US Bureau of Land Management. (2015). NEPA HOTSHEET, 3 August 2015, BLM Wyoming Land Use Plans and Proposed Projects. htpp://www.blm.gov/style/medialib/blm/wy/information/ NEPA.Par.24843.File.dat/hot sheet.pdf. Accessed 15 August 2015.

24. Applegate, D. H., \& Owens, M. L. (2014). Oil and gas impacts on Wyoming's sage-grouse: summarizing the past and predicting the foreseeable future. Human-Wildlife Interactions, 8(2), 284-290. 
25. Encana. (2011). Plan of development, normally pressured lance natural gas development project (6-29-11), Encana Oil \& Gas (USA) Inc. CO: Denver.

26. Evans, J. S., \& Kiesecker, J. M. (2014). Shale, gas, wind and water: assessing the potential cumulative impacts of energy development on ecosystem services within the Marcellus Play. PloS One, 9(2), 1-9.

27. Copeland, H. E., Pocewicz, A., Naugle, D. E., Griffiths, T., Keinath, D., Evans, J., \& Platt, J. (2013). Measuring the effectiveness of conservation: a novel framework to quantify the benefits of sagegrouse conservation policy and easements in Wyoming. PloS One, $8(6), 1-14$

28. Wilbert, M., Thomson, J., \& Culver, N. W. (2008). Analysis of habitat fragmentation from oil and gas development and its impact on wildlife: a framework for public land management planning. Washington DC: The Wilderness Society.

29. Buto, S. G., Kenney, T. A., \& Gerner, S. J. (2010). Land disturbance associated with oil and gas development and effects of development-related land disturbance on dissolved-solids loads in streams in the Upper Colorado River Basin, 1991, 2007, and 2025. U.S. Geological Survey Scientific Investigations Report 2010 5064, p. 56. http://pubs.usgs.gov/sir/2010/5064. Accessed 11 June 2013

30. Copeland, H. E., Doherty, K. E., Naugle, D. E., Pocewicz, A., \& Kiesecker, J. M. (2009). Mapping oil and gas development potential in the US Intermountain West and estimating impacts to species. PloS One, 4(10), 1-7.

31. USDI-USFWS. (2015). Greater sage-grouse. http://www.fws.gov/ greatersagegrouse. Accessed 25 December 2015.

32. Garman, S. L., \& McBeth, J. L. (2015). Digital representation of oil and natural gas well pad scars in southwest Wyoming-2012 update. U.S. Geological Survey Data Series 934 [abs.]. doi:10.3133/ds934. Accessed 12 September 2014

33. O'Donnell, M. S., Fancher, T. S., Freeman, A. T., Zeigler, A. E., Bowen, Z. H., \& Aldridge, C. L. (2014). Large scale Wyoming transportation data - a resource planning tool. U.S. Geological Survey Data Series 821, p. 21. doi: 10.3133/ds821. Accessed 12 December 2014.

34. Assal, T. J., Garman, S. L., Bowen, Z. H., Anderson, P. J., Manier, D., \& McDougal, R. R. (2012). Data resources for the Wyoming Landscape Conservation Initiative (WLCI) Integrated Assessment (IA) [abs.]. U.S. Geological Survey Data Series 700. http://pubs. usgs.gov/ds/700. Accessed 15 March 2013.

35. State of Wyoming. (2011). State of Wyoming Executive Department, Executive Order 2011-5, greater sage-grouse core area protection. Cheyenne: Office of the Governor of Wyoming.

36. US Bureau of Land Management. (2007). Record of decision, environmental impact statement for the Atlantic Rim natural gas field development project, Carbon County, Wyoming, U.S. Department of the Interior, Bureau of Land Management. Cheyenne, Wyoming: Wyoming State Office.

37. Molvar, E. M. (2003). Drilling smarter: using minimum-footprint directional drilling to reduce oil and gas impacts in the Intermountain West (p. 32). Laramie, WY: Biodiversity Conservation Alliance.

38. Wyoming Game and Fish Department. (2010). Recommendations for development of oil and gas within important wildlife habitats. http://wgfd.wyo.gov/Web2011/Departments/Wildlife/pdfs/ HABITAT OILGASRECOMMENDATIONS0000333.pdf. Accessed 8 November 2014.

39. ESRI. (2011). ArcGIS Desktop: Release 10. Redlands, CA: Environmental Systems Research Institute.

40. Ingelfinger, F., \& Anderson, S. (2004). Passerine response to roads associated with natural gas extraction in a sagebrush steppe habitat. Western North American Naturalist, 64(3), 385-395.

41. Gregory, A. J., \& Beck, J. L. (2014). Spatial heterogeneity in response of male greater sage-grouse lek attendance to energy development. PloS One, 9(6), 1-8.
42. Manier, D. J., Wood, D. J. A., Bowen, Z. H., Donovan, R. M., Holloran, M. J., Juliusson, L. M., Mayne, K. S., Oyler-McCance, S. J., Quamen, F. R., Saher, D. J., \& Titolo, A. J. (2013). Summary of science, activities, programs, and policies that influence the rangewide conservation of greater sage-grouse (Centrocercus urophasianus). U.S. Geological Survey Open-File Report 2013 1098. P. 170 http://pubs.usgs.gov/of/2013/1098. Accessed 15 July 2014

43. Sawyer, H. H., Lindzey, F. G., \& Jellison, B. A. (1998). Applying GIS technology to test an elk habitat effectiveness model in northcentral Wyoming. In J. C. de Vos Jr. (Ed.), Proceedings of the 1997 Deer/Elk Workshop, Rio Rico, AZ (pp. 176-183). Phoenix, AZ: Arizona Game and Fish Department.

44. Sawyer, H., Nielson, R. M., Lindzey, F., \& McDonald, L. L. (2006). Winter habitat selection of mule deer before and during development of a natural gas field. Journal of Wildlife Management, 70(2), 396-403.

45. Sawyer, H., Kauffman, M. J., Middleton, A. D., Morrison, T. A., Nielson, R. M., \& Wyckoff, T. B. (2013). A framework for understanding semi-permeable barrier effects on migratory ungulates. Journal of Applied Ecology, 50, 68-78.

46. Lutz, D. W., Wakeling, B. F., Carpenter, L. H., Stroud, D., Cox, M., McWhirter, D., Rosenstock, S., Bender, L. C., \& Reeve, A. R. (2003). Impacts and changes to mule deer habitat. In J. C. de Vos Jr., M. R. Conover, \& N. E. Headrick (Eds.), Mule deer conservation: issues and management strategies (pp. 13-61). Logan, UT: Jack H. Berryman Institute Press, Utah State University.

47. Lyon, L. J. (1979). Habitat effectiveness for elk as influenced by roads and cover. Journal of Forestry, 77(10), 658-600.

48. Lyon, L. J. (1983). Road density models describing habitat effectiveness for elk. Journal of Forestry, 81(9), 592-596.

49. Thomson, J. L., Schaub, T. S., Culver, N. W., \& Aengst, P. C. (2005). Wildlife at a crossroads: energy development in western Wyoming. Washington, DC: The Wilderness Society.

50. Forman, R. T. (1999). Estimate of the area affected ecologically by the road system in the United States. Conservation Biology, 14(1), 31-35.

51. Manier, D. J., Aldridge, C. L., O'Donnell, M., \& Schell, S. J. (2014). Human infrastructure and invasive plant occurrence across rangelands of southwestern Wyoming, USA. Rangeland Ecology \& Management, 67(2), 160-172.

52. Harju, S. M., Dzialak, M. R., Taylor, R. C., Hayden-Wing, L. D., \& Winstead, J. B. (2010). Thresholds and time lags in effects of energy development on greater sage-grouse populations. Journal of Wildlife Management, 74(3), 437-448.

53. Johnson, D. H., Holloran, M. J., Connelly, J. W., Hanser, S. E., Amundson, C. L., \& Knick, S. T. (2011). Influences of environmental and anthropogenic features on greater sage-grouse populations, 1997-2007. In S. T. Knick \& J. W. Connelly (Eds.), Greater sage-grouse: ecology and conservation of a landscape species and its habitats. Studies in avian biology series (Vol. 38, pp. 407-450). Berkeley, California: University of California Press.

54. SAS Institute. (2010). Version 9.2. Cary, NC: SAS Institute.

55. Prato, T. (2007). Evaluating land use plans under uncertainty. Land Use Policy, 24(1), 165-174.

56. EPA. (2010). Directional drilling technology. http://www.epa.gov/ cmop/docs/dir-drilling.pdf. Accessed 29 August 2015.

57. Keuengoua, C. D. S., \& Amorin, R. (2011). Well spacing for horizontal wells. Research Journal of Applied Sciences, Engineering and Technology, 3(6), 486-493.

58. Wisdom, M., Meinke, C., Knick, S. T., \& Schroeder, M. A. (2011). Factors associated with extirpation of sage-grouse. In S. T. Knick \& J. W. Connelly (Eds.), Greater sage-grouse: ecology and conservation of a landscape species and its habitats. Studies in avian biology series (Vol. 38, pp. 451-472). Berkeley, California: University of California Press. 
59. Sawyer, H., Nielson, R. M., Lindzey, F., Keith, L., Powell, J. H., \& Abraham, A. A. (2007). Habitat selection of rocky mountain elk in a nonforested environment. Journal of Wildlife Management, 71(3), 868-874.

60. Stilwell, D. P. (2015). Final reasonable foreseeable development scenario for oil and gas, Rock Springs Field Office, Wyoming. U.S. Cheyenne, Wyoming: Department of the Interior, Bureau of Land Management, Reservoir Management Group.
61. US Department of the Interior and US Department of Agriculture. (2007). Surface operating standards and guidelines for oil and gas exploration and development. BLM/WO/ST-06/021+3071/REV 07 (p. 84). Denver, Colorado: Bureau of Land Management.

62. Hethcoat, M. G., \& Chalfoun, A. D. (2015). Energy development and avian nest survival in Wyoming, USA: a test of a common disturbance index. Biological Conservation, 184, 327-334. 